\title{
PENGARUH PUPUK HAYATI DAN BAHAN ORGANIK TERHADAP POPULASI DAN BIOMASSA CACING TANAH PADA PERTANAMAN BAWANG MERAH (Allium ascalonicum L) DI KECAMATAN MERBAU MARATAM KABUPATEN LAMPUNG SELATAN
}

\author{
EFFECT OF BIOFERTILIZER AND ORGANIC MATTER ON POPULATION \\ AND BIOMASS OF EARTHWORM IN SHALLOT (Allium ascalonicum L) \\ CULTIVATION IN MERBAU MATARAM, \\ SOUTH LAMPUNG REGENCY
}

\author{
Annove Kurnia Arofi", Sri Yusnaini, Kus Hendarto dan Syamsul Arif \\ Jurusan Agroteknologi Fakultas Pertanian Universitas Lampung \\ JL. Prof. Dr. Soemantri Brojonegoro, No. 1 Bandar Lampung 35145 \\ Universitas Lampung, Bandar Lampung, 35145 Indonesia. \\ *Email:annove.ka@gmail.com
}

\begin{abstract}
This study aimed to determine the effect of biofertilizer, organic matter and the interaction between biofertilizer and organic matter on population, biomass of earthworm and shallot production. This experiment was conducted in Merbau Mataram, South Lampung Regency on September-December 2017, designed by using Randomize Block Design (RBD) with two factors, i.e. : Biofertilizer application consists of biofertilizer and non biofertilizer and organic matter application consists of chicken manure, cow manure, oyster mushroom baglog and straw compost. Analysis of variance (anova) was carried out using a significance level of 0,05 after verifying the additivity (Tukey's test) and homogeneity of variance (Bartlett's test) of the data. When a significant effect was revealed in the anova, the mean separations among treatments were obtained by least significant difference (LSD 0.05). The results showed that application of biofertilizer (Bio max grow) increased earthworm population in 37 days after planting at $10-20 \mathrm{~cm}$ depth and 70 days after planting at $0-10$ and $10-20 \mathrm{~cm}$ depth, biofertilizer application also affected earthworm biomass and shallot production in 70 days after planting. Oyster mushroom application gave the best effect compared to the other organic matter on population and biomass of earthworm and shallot production.
\end{abstract}

Keywords: Biofertilizer, earthworm, organic matter, shallot

\begin{abstract}
ABSTRAK
Penelitian ini bertujuan untuk mengetahui dan mempelajari pengaruh aplikasi pupuk hayati, jenis bahan organik yang berbeda, dan interaksi pemberian bahan organik dan aplikasi pupuk hayati terhadap populasi cacing dan biomassa cacing tanah serta produksi bawang merah. Penelitian ini dilakukan di Kecamatan Merbau
\end{abstract}


Mataram Kabupaten Lampung Selatan pada bulan September-Desember 2017. Penelitian ini menggunakan rancangan acak kelompok (RAK) yang disusun secara faktorial. Faktor pertama digunakan pupuk hayati dengan diberi perlakuan dan tanpa diberi, sedangkan faktor kedua digunakan bahan organik dengan 4 jenis bahan organik yaitu pupuk kandang kotoran ayam, pupuk kandang kotoran sapi, baglog jamur tiram, dan kompos jerami. Data yang diperoleh dihomogenkan ragamnya menggunakan Uji Bartlett dan kemenambahan data diuji dengan Uji Tukey. Setelah asumsi terpenuhi data diolah dengan analisis ragam dan diuji lanjut dengan Uji Beda Nyata terkecil pada taraf 5\%. Hasil penelitian menunjukkan bahwa pemberian pupuk hayati (Bio max grow) meningkatkan populasi cacing tanah pada pengamatan $37 \mathrm{HST}$ di kedalaman 10-20 cm dan pada pengamatan 70 HST di kedalaman 0-10 cm dan 10-20 cm, dan pemberian pupuk hayati bepengaruh terhadap biomassa cacing tanah dan produksi bawang merah pada pengamatan 70 HST .Pemberian baglog jamur memberikan pengaruh yang terbaik diantara bahan organik lainnya terhadap populasi cacing tanah, biomassa cacing tanah dan produksi bawang merah.

Kata Kunci : Bawang merah, bahan organik, cacing tanah, dan pupuk hayati.

\section{PENDAHULUAN}

Program peningkatan produksi pangan yang dicanangkan oleh kementrian pertanian RI ditujukan untuk menjadikan Indonesia swasembada pangan. Beberapa komoditas unggulan dalam program tersebut yakni padi, jagung, kedelai, aneka cabai dan bawang merah (Kementan, 2015).

Bawang merah merupakan komoditas yang digunakan oleh seluruh lapisan masyarakat. Bawang merah bermanfaat sebagai bumbu masakan, dan juga pengobatan

tradisional. Rendahnya produktivitas bawang merah karena penggunaan bahan organik oleh petani sehingga akan berpengaruh pada kualitas tanah seperti struktur tanah (Direktorat Pangan dan Pertanian, 2014).Teknik budidaya bawang merah memerlukan kondisi tanah yang subur, gembur, kaya bahan organik, memiliki kadar $\mathrm{pH}$ tanah 6,5-7. Bawang merah dapat tumbuh pada ketinggian tempat 10-800 mdpl dengan suhu udara $25-32{ }^{\circ} \mathrm{C}$ serta pengairan yang cukup dalam teknik budidaya bawang merah (Maftu'ah dan Maulia, 2009).

Pupuk hayati adalah pupuk yang mengandung berbagai jenis mikroba yang bermanfaat untuk meningkatkan kesuburan tanah secara biologi, pupuk hayati bisa berupa padatan atau cairan. Beberapa jenis mikroba yang terkandung dalam pupuk hayati adalah Azospirilium sp. untuk penambat nitrogen, Pseudomonas sp. untuk pelarut fosfat, Lactobacillus sp., mikroba selulotik dan lainnya (Andriawan 2010 dalam Prayoga, 2016). Berbagai jenis limbah pertanian seperti pupuk kandang dan sisa tanaman seperti jerami dan baglog jamur tiram dapat digunakan sebagai sumber bahan organik. Berbagai jenis limbah pertanian yang dapat dimanfaatkan dalam meningkatkan kesuburan tanah.

Salah satu biota tanah yang sangat berperan aktif dalam mendukung kesuburan tanah adalah cacing tanah. Cacing tanah memiliki kemampuan membuat lubang sehingga mampu menurunkan kepadatan tanah, meningkatkan kapasitas infiltrasi, mengurangi aliran 
permukaan dan erosi, serta melalui kotoran cacing tanah yang dihasilkan dapat menambah unsur hara bagi tanaman. Populasi cacing tanah terdapat pada tanah yang mengandung bahan organik, bahan organik berperan sebagai sumber energi bagi cacing tanah. Populasi cacing tanah berpengaruh terhadap kondisi tanah dalam memperbaiki keadaan tanah. Aktivitas cacing tanah dalam membuat lubang-lubang saluran di dalam tanah, menyebabkan air dapat dengan mudah menembus ke dalam tanah, sehingga diduga ikut berperan dalam meningkatkan permeabilitas tanah pada tanah yang terkompaksi (Marzuki dkk., 2011).

Pemberian pupuk kandang, limbah pertanian, dan aplikasi pupuk hayati pada lahan pertanian diharapkan dapat meningkatkan populasi cacing tanah. Dengan meningkatnya populasi cacing tanah maka akan meningkatkan kesuburan tanah yang pada akhirnya akan meningkatkan pertumbuhan dan produksi tanaman bawang merah.

\section{BAHAN DAN METODE}

Penelitian ini dilaksanakan di Kecamatan Merbau Mataram Kabupaten Lampung Selatan pada bulan September-Desember 2017. Bahan- bahan yang digunakan adalah Benih bawang merah varietas bima brebes, pupuk hayati (Bio Max Grow), bahan organik berupa pupuk kandang (kotoran sapi dan kotoran ayam), jerami, dan baglog jamur, pupuk NPK, $\mathrm{KCl}$, dethine (fungisida), Plant Catalyst. Faktor pertama yaitu Pupuk Hayati (Bio Max Grow) dengan konsentrasi $5 \mathrm{ml} / 1$ setiap petak dan Faktor kedua menggunakan bahan organik berupa pupuk kandang kotoran sapi, pupuk kandang kotoran ayam, jerami, dan baglog jamur tiram sebanyak $2,4 \mathrm{~kg}$ perpetak sesuai perlakuan. Perlakuan pupuk hayati diberikan pada saat umur 3 minggu, 5 minggu dan 7 minggu setelah tanam dengan konsentrasi $5 \mathrm{ml} / 1$ air. Berdasarkan kombinasi perlakuan tersebut yang dilakukan sebanyak 3 ulangan diperoleh 24 satuan percobaan. Setiap petak berisi 40 tanaman dengan jarak tanam $15 \mathrm{~cm}$ x $20 \mathrm{~cm}$.

Penelitian ini menggunakan rancangan acak kelompok yang disusun secara faktorial. Pengelompokan (ulangan) dikategorikan berdasarkan kemiringan lahan. Data yang diperoleh akan diuji homogenitas menggunakan Uji Bartlett dan penambahan data diuji Aditivitas menggunakan uji tukey, apabila asumsi terpenuhi maka data akan dianalasis dengan analisis sidik ragam dan dilanjutkan dengan Uji BNT pada taraf 5\%.

Pengamatan yang dilakukan dengan mengambil sampel cacing tanah dengan menggunakan metode hand sorting pada kedalaman 0-10 cm dan kedalaman 10-20 cm pada pengamatan sebelum olah tanah, pengamatan 37 HST dan 70 HST. Variabel utama yaitu cacing tanah dihitung populasi dan biomassanya. Sedangkan untuk variabel pendukung menggunakan kadar air tanah, suhu tanah, kemasaman tanah, C-organik, sampel bobot umbi bawang merah saat panen dan dikeringkan.

\section{HASIL DAN PEMBAHASAN}

\section{Populasi Cacing Tanah}

Hasil rekapitulasi penelitian pengaruh pupuk 
hayati dan bahan organik menunjukkan adanya pengaruh perlakuan terhadap variabel pengamatan populasi dan biomassa cacing tanah serta bobot umbi bawang merah (Tabel 1).

Perlakuan pupuk hayati berpengaruh nyata terhadap semua variabel pengamatan kecuali terhadap variabel pengamatan populasi cacing tanah $0-10 \mathrm{~cm}$ (37 HST) dan biomassa cacing tanah (37 HST). Perlakuan bahan organik berpengaruh nyata terhadap semua variabel pengamatan kecuali populasi cacing tanah 0-10 cm (37 HST). Sedangkan interaksi kedua perlakuan terjadi pada populasi cacing tanah $0-10 \mathrm{~cm}$ (37 HST) dan pada variabel pengamatan lainnya tidak berbeda nyata.

Berdasarkan hasil penelitian (Tabel 2) terlihat bahwa pada populasi cacing tanah di kedalaman 0-10 pengamatan $37 \mathrm{HST}$, pengaruh perlakuan pupuk hayati dan jenis bahan organik menunjukkan interkasi yang nyata. Tidak terdapat perbedaan populasi cacing tanah antara perlakuan diberi pupuk hayati dengan yang tidak diberi, hal ini diduga karena efek mikroorganisme yang terkandung pada pupuk hayati selama 37 HST belum bekerja secara maksimal dalam mendekomposisi bahan organik. Hal tersebut menyebabkan sumber makanan bagi perkembangan cacing tanah relatif sama sehingga populasi cacing tanah juga relatif sama (tidak berbeda).

Tabel 1. Rekapitulasi hasil penelitian pengaruh perlakuan pupuk hayati dan bahan organik

\begin{tabular}{|c|c|c|c|c|c|c|c|c|c|}
\hline \multirow{4}{*}{ Perlakuan } & \multicolumn{9}{|c|}{ Variabel pengamatan } \\
\hline & \multicolumn{4}{|c|}{ Populasi cacing tanah } & \multicolumn{4}{|c|}{ Biomassa cacing tanah } & \multirow{3}{*}{ Bobot umbi } \\
\hline & \multicolumn{2}{|c|}{$37 \mathrm{HST}$} & \multicolumn{2}{|c|}{$70 \mathrm{HST}$} & \multicolumn{2}{|c|}{$37 \mathrm{HST}$} & \multicolumn{2}{|c|}{$70 \mathrm{HST}$} & \\
\hline & $0-10 \mathrm{~cm}$ & $10-20 \mathrm{~cm}$ & $0-10 \mathrm{~cm}$ & $10-20 \mathrm{~cm}$ & $0-10 \mathrm{~cm}$ & $10-20 \mathrm{~cm}$ & $0-10 \mathrm{~cm}$ & $10-20 \mathrm{~cm}$ & \\
\hline Pupuk hayati & tn & $*$ & $*$ & $*$ & tn & tn & $*$ & $*$ & $*$ \\
\hline Bahan organik & th & $*$ & * & $*$ & $*$ & $*$ & $*$ & $*$ & $*$ \\
\hline interaksi & * & th & th & th & th & tn & th & tn & tn \\
\hline
\end{tabular}

Keterangan : Tanda $\left(^{*}\right)$ menunjukkan adanya korelasi yang sangat nyata; tanda (tn) menunjukkan bahwa tidak berkorelasi.

Tabel 2. Hasil uji lanjut BNT 5\% interaksi antara pupuk hayati dan jenis bahan organik terhadap populasi

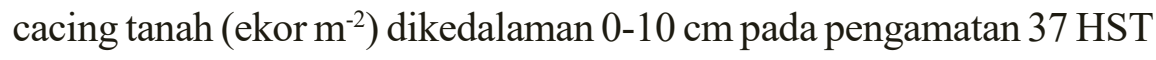

\begin{tabular}{|c|c|c|c|c|}
\hline \multirow{3}{*}{ Pupuk hayati } & \multicolumn{4}{|c|}{ Bahan organik } \\
\hline & $\mathrm{P}_{1}$ & $\mathrm{P}_{2}$ & $\mathrm{P}_{3}$ & $\mathrm{P}_{4}$ \\
\hline & \multicolumn{4}{|c|}{ Populasi cacing tanah $\left(\right.$ ekor $\left.\mathrm{m}^{-2}\right)$} \\
\hline \multirow[t]{2}{*}{ B0 ( Tanpa pupuk hayati) } & $27 \mathrm{~b}$ & $59 a$ & $69 \mathrm{a}$ & $48 \mathrm{a}$ \\
\hline & B & $\mathrm{A}$ & $\mathrm{A}$ & $\mathrm{AB}$ \\
\hline \multirow[t]{2}{*}{$\mathrm{B}_{1}$ ( Diberi pupuk hayati) } & $75 \mathrm{a}$ & $48 \mathrm{a}$ & $75 \mathrm{a}$ & $48 \mathrm{a}$ \\
\hline & A & B & A & B \\
\hline BNT $5 \%$ & \multicolumn{4}{|c|}{27} \\
\hline
\end{tabular}

Keterangan : $\mathrm{B}_{0}$ ( Tanpa pupuk Hayati) ; $\mathrm{B}_{1}$ ( Diberi pupuk hayati) ; $\mathrm{P}_{1}$ ( Pupuk kandang ayam) ; $\mathrm{P}_{2}$ ( Pupuk kandang sapi) ; $\mathrm{P}_{3}$ (Baglog jamur) $\mathrm{P}_{4}$ (Kompos Jerami). Angka-angka yang diikuti huruf yang sama baik secara vertikal (huruf kecil) maupun horizontal (huruf besar) tidak menunjukkan berbeda dengan uji lanjut BNT 5\%. Angka-angka yang diikuti dengan huruf kecil dibaca secara vertikal dan huruf besar dibaca secara horizontal. 
Tabel 3. Hasil uji lanjut BNT 5\% pengaruh pupuk hayati dan jenis bahan organik terhadap populasi cacing tanah

\begin{tabular}{|c|c|c|c|}
\hline \multirow[b]{2}{*}{ Perlakuan } & \multicolumn{3}{|c|}{ Populasi Cacing tanah (ekor $\mathrm{m}^{-2}$ ) } \\
\hline & $\begin{array}{c}\text { Kedalaman } 10-20 \mathrm{~cm} 37 \\
\text { HST }\end{array}$ & $\begin{array}{c}\text { Kedalaman 0-10 cm } 70 \\
\text { HST }\end{array}$ & $\begin{array}{c}\text { Kedalaman } 10-20 \mathrm{~cm} \\
70 \mathrm{HST}\end{array}$ \\
\hline $\mathrm{B}_{0}$ ( Tanpa pupuk Hayati) & $39 \mathrm{~b}$ & $62(8) b$ & $59 \mathrm{~b}$ \\
\hline $\mathrm{B}_{1}$ ( Diberi pupuk hayati) & $55 \mathrm{a}$ & $84(9) \mathrm{a}$ & $80 \mathrm{a}$ \\
\hline BNT $5 \%$ & 10 & 1 & 17 \\
\hline $\mathrm{P}_{1}$ ( Pupuk kandang ayam) & $32 \mathrm{c}$ & $50(7) b$ & $51 \mathrm{~b}$ \\
\hline $\mathrm{P}_{2}$ ( Pupuk kandang sapi) & $54 \mathrm{~b}$ & $87(9)$ a & $78 \mathrm{a}$ \\
\hline $\mathrm{P}_{3}($ Baglog jamur $)$ & $70 \mathrm{a}$ & $91(9) \mathrm{a}$ & $98 \mathrm{a}$ \\
\hline $\mathrm{P}_{4}($ Kompos Jerami) & $32 \mathrm{c}$ & $61(8) b$ & $51 \mathrm{~b}$ \\
\hline BNT $5 \%$ & 14 & 1 & 24 \\
\hline
\end{tabular}

Keterangan : Nilai tengah yang diikuti oleh huruf yang sama, tidak berbeda nyata berdasarkan uji BNT pada taraf 5\%.

Pada kedalaman tanah 10-20 $\mathrm{cm}$ baik pada pengamatan 37 HST maupun pengamatan 70 HST hasil penelitian(Tabel3) menyatakan bahwa pemberian pupuk hayati menghasilkan populasi cacing tanah yang lebih banyak dibandingkan tanpa pupuk hayati. Hal ini mungkin disebabkan karena mikroba yang diberikan melalui penyiraman pupuk hayati menjadikan tanah lebih subur. Mikroorganisme yang disiramkan masuk ke dalam tanah terbawa oleh air penyiraman atau air hujan sehingga menyebar keseluruh petakan lahan. Demikian pula dengan jenis bahan organik yang menghasilkan populasi cacing tanah yang berbeda .

Jenis bahan organik yang berbeda memberikan pengaruh yang berbeda pada populasi cacing tanah, populasi cacing tanah terbanyak terdapat pada pemberian baglog jamur yang relatif tidak berbeda dengan pupuk kandang sapi dan diikuti oleh kompos jerami yang tidak berbeda dengan pupuk kandang ayam. Tingginya populasi cacing tanah pada perlakuan limbah baglog jamur disebabkan baglog jamur mengandung 49\% C-organik dan $81 \% \mathrm{C} / \mathrm{N}$ rasio. Baglog jamur terbuat dari 90\% serbuk gergaji, 7\% bekatul, 1\% kapur, 2\% tapioka, dan 45-60\% volume air (Muchlisin,2012 dalam Syamfullah, 2016). Selama proses pertumbuhan jamur tiram, misselia jamur merombak serat kasar ( selulosa) untuk sumber makanan sehingga tersisa hemiselulosa (Rizky, 2017).

Kandungan bahan organik yang membentuk baglog jamur tersebut memungkinkan terbentuknya sifat fisik tanah yang lebih baik bila dibandingkan pupuk kandang ayam dan jerami padi. Sifat fisik tersebut yakni tanah lebih gembur sehingga pori-pori makro yang terbentuk cukup banyak dan tata udara tanah menjadi lebih baik. Kemampuan sifat fisik tanah lainnya yaitu menahan air cukup baik dan ideal bagi perkembangan cacing tanah sehingga tidak menimbulkan kelebihan air. Selain itu, suhu tanah menjadi lebih ideal. Kandungan serat kasar (selulosa) dalam tanah yang masih cukup 
tinggi merupakan bahan yang cukup banyak untuk didekomposisi oleh mikroorganisme dan sebagai sumber makanan bagi cacing tanah, sehingga populasi cacing tanah dapat berkembangbiak dengan baik.

Pupuk kandang ayam menghasilkan populasi cacing tanah yang terendah dan relatif sama dengan jerami padi. Hal ini didukung oleh penelitian Rotupa, dkk., (2014) yang menyatakan bahwa pupuk kandang ayam mempunyai tekstur yang relatif padat sehingga jika digunakan sebagai media harus dicampur dengan bahan tumbuhan untuk memperbaiki porositas, karena tidak mempunyai campuran tersebut cacing tanah kurang menyukai ini. Hal ini berpengaruh untuk cacing tanah yang menyukai tanah subur dan gembur dengan dipenuhi serat-serat halus hasil dari bahan organik.

Pada pupuk kandang ayam menghasilkan populasi yang lebih rendah dikarenakan pupuk kandang ayam campuran dari kotoran ayam dan sekam padi. Reaksi panas terbentuk karena proses penguraian oleh mikroorganisme yang berlangsung cepat pada kotoran ayam dan melambat pada bahan sekam padi, sehingga berpengaruh pada kelembaban dan suhu tanah. Cacing tanah membutuhkan kelembaban yang stabil dan optimum dan suhu optimum 20 fl $\mathrm{C}$ sampai $25 \mathrm{fl}$ C. Cacing tanah menyukai tempat yang lembab dan gelap. Menurut Febrita, dkk., (2015) pupuk kandang ayam juga memiliki zat amoniak yang tinggi sehingga tidak disukai oleh cacing tanah. Perbedaan populasi cacing tanah tersebut selain disebabkan oleh perbedaan kandungan pada bahan organik juga disebabkan oleh kelembaban tanah dan suhu yang ideal bagi perkembangan cacing tanah di kedalaman 10-20 cm. .
Berdasarkan data yang diperoleh dari pengamatan populasi cacing tanah pada umur $37 \mathrm{HST}$ dan 70 HST, Perlakuan menggunakan pupuk hayati jauh lebih baik dari pada tidak menggunakan pupuk hayati. Terlihat bahwa pemberian pupuk hayati menunjukkan pengaruh lebih tinggi pada umur 70 HST, sedangkan perlakuan tanpa pupuk hayati menunjukkan pengaruh terendah pada umur 37 HST. Hal ini disebabkan karena pupuk hayati mengandung bahan aktifmikroba yang mampu menghasilkan senyawa yang berperan dalam proses penyediaan unsur hara dalam tanah (Willy, dkk., 2011). Dengan tersedianya unsur hara menyebabkan peningkatan cacing tanah. Cacing tanah akan berkembang, kokon cacing tanah menetas dengan waktu inkubasi 2-3 minggu (Subowo,2008). Hal ini menyebabkan pertambahannya cacing tanah pada umur $70 \mathrm{HST}$.

\section{Biomassa Cacing Tanah}

Hasilpenelitian menunjukkan bahwa adanya pengaruh terhadap pupuk hayati dan bahan organik terhadap biomassa cacing tanah yang ditampilkan pada Tabel 4.

Pertambahan biomassa sejalan dengan meningkatnya populasi cacing tanah, seperti yang terlihat pada hasil pengamatan biomasa cacing tanah pada kedalaman 0-10 $\mathrm{cm}$ sampai $10-20 \mathrm{~cm}$ pada pengamatan $30 \mathrm{HST}$ dan $70 \mathrm{HST}$. Hal tersebut menunjukkan pada 37 HST dan 70 HST memiliki bobot dan ukuran cacing tanah yang relatif sama.

Pada pengamatan 37 HST di kedalaman 0$10 \mathrm{~cm}$ dan 10-20 cm bobot biomassa cacing tanah 
Tabel 4. Hasil uji lanjut BNT 5\% pengaruh pupuk hayati dan jenis bahan organik terhadap biomassa cacing tanah

\begin{tabular}{lcccc}
\hline \multirow{2}{*}{ Perlakuan } & \multicolumn{4}{c}{ Biomassa cacing tanah $\left(\right.$ gram $\left.\mathrm{m}^{-2}\right)$} \\
\cline { 2 - 5 } & Kedalaman 0-10 cm & Kedalaman 10-20 cm & Kedalaman 0-10 cm & Kedalaman 10-20 cm \\
\hline $\mathrm{B}_{0}$ ( Tanpa pupuk Hayati) & $37 \mathrm{HST}$ & $37 \mathrm{HST}$ & $70 \mathrm{HST}$ & $70 \mathrm{HST}$ \\
$\mathrm{B}_{1}$ ( Diberi pupuk hayati) & $3,19 \mathrm{a}$ & $3,00 \mathrm{a}$ & $4,87 \mathrm{~b}$ & $7,19 \mathrm{~b}$ \\
\hline BNT 5 \% & $3,51 \mathrm{a}$ & $4,17 \mathrm{a}$ & $6,55 \mathrm{a}$ & $10,20 \mathrm{a}$ \\
\hline $\mathrm{P}_{1}$ ( Pupuk kandang & 1,06 & 1,19 & 1,67 & 2,5 \\
$\mathrm{P}_{2}$ ( Pupuk kandang sapi) & $2,56 \mathrm{~b}$ & $1,76 \mathrm{c}$ & $3,63 \mathrm{~b}$ & $5,01 \mathrm{~b}$ \\
$\mathrm{P}_{3}$ ( Baglog jamur) & $2,61 \mathrm{~b}$ & $5,36 \mathrm{a}$ & $7,23 \mathrm{a}$ & $11,33 \mathrm{a}$ \\
$\mathrm{P}_{4}$ ( Kompos Jerami) & $5,52 \mathrm{a}$ & $4,35 \mathrm{ab}$ & $7,71 \mathrm{a}$ & $12,88 \mathrm{a}$ \\
\hline BNT 5\% & $2,69 \mathrm{~b}$ & $2,88 \mathrm{bc}$ & $4,27 \mathrm{~b}$ & $5,55 \mathrm{~b}$ \\
\hline
\end{tabular}

Keterangan : Nilai tengah yang diikuti oleh huruf yang sama, tidak berbeda nyata berdasarkan uji BNT pada taraf 5\%.

Tabel 5. Hasil uji lanjut BNT 5\% pengaruh pupuk hayati dan jenis bahan organik terhadap bobot umbi pertanaman bawang merah.

\begin{tabular}{lc}
\hline \multicolumn{1}{c}{ Perlakuan } & Bobot umbi pertanaman (gram) \\
\hline $\mathrm{B}_{0}$ ( Tanpa pupuk Hayati) & $127 \mathrm{~b}$ \\
$\mathrm{~B}_{1}$ ( Diberi pupuk hayati) & $138 \mathrm{a}$ \\
\hline BNT 5\% & 8 \\
\hline $\mathrm{P}_{1}$ ( Pupuk kandang ayam) & $106 \mathrm{~b}$ \\
$\mathrm{P}_{2}$ ( Pupuk kandang sapi) & $141 \mathrm{a}$ \\
$\mathrm{P}_{3}$ ( Baglog jamur) & $166 \mathrm{a}$ \\
$\mathrm{P}_{4}$ ( Kompos Jerami) & $112 \mathrm{ab}$ \\
\hline
\end{tabular}

BNT 5\% 11

Keterangan : Nilai tengah yang diikuti oleh huruf yang sama pada kolom yang sama, tidak berbeda nyata berdasarkan uji BNT pada taraf $5 \%$.

relatif sama, sedangkan pada pengamatan $70 \mathrm{HST}$ dikedalaman 0-10 $\mathrm{cm}$ dan 10-20 $\mathrm{cm}$ terjadi peningkatan bobot biomassa cacing tanah dari pengamatan $37 \mathrm{HST}$. Hal ini dikarenakan cacing tanah berkembang dalam pertumbuhan biomassanya. Pada pengamatan $70 \mathrm{HST}$ di kedalaman 10-20 $\mathrm{cm}$ paling tinggi bobot biomassa cacing tanah dikarenakan cacing tanah paling senang dengan keadaaan tanah yang lembab dan tidak terpapar matahari, faktor lainnya juga pada kedalaman $0-10 \mathrm{~cm}$ kelembaban tanah lebih rendah dan tanah cenderung lebih kering dibandingkan 10-20 cm. Kesuburan tanah dan ketersediaan hara bagi tanaman akan ditunjukkan melalui produksi yang tinggi, keberadaan populasi cacing tanah dapat digunakan sebagai indikator kesuburan tanah.

\section{Bobot Umbi Bawang Merah}

Berdasarkan hasil penelitian (Tabel 5) bobot umbi pertanaman bawang merah terlihat bahwa perlakuan menggunakan pupuk hayati lebih baik 
dibandingkan tanpa pemberian pupuk hayati. Sedangkan pada perlakuan bahan organik, perlakuan baglogjamurmenghasilkan bobot umbi yang lebih tinggi dibandingkan pupuk kandang ayam tetapi tidak berbeda dengan pupuk kandang sapid an kompos jerami. Perbedaan bobot umbi pertanaman tersebut sejalan dengan banyaknya populasi cacing tanah dan biomassa cacing tanah. Rata-rata bobot umbi bawang merah pada masing-masing perlakuan yaitu; baglog jamur (166,00 gram), pupuk kandung sapi (141, 00 gram), kompos jerami (112,15 gram) dan pupuk kandang ayam (105,80 gram).

\section{Korelasi Antara Sifat Tanah dengan Populasi Cacing Tanah, Biomassa cacing Tanah, dan Produksi Bawang Merah.}

Hasil analisis tanah yang digunakan sebagai variabel pendukung berupa sifat kimia tanah yang ditampilkan pada Tabel 6 .

Berdasarkan hasil uji korelasi sifat kimia tanah (Tabel 7), C-organik berkorelasi nyata positif dengan biomassa cacing tanah, bobot umbi basah dan bobot umbi kering. Pada variabel kadar air berkorelasi nyata negatif dengan populasi cacing tanah, biomassa cacing tanah dan bobot umbi basah. Sedangkan suhu dan kemasaman tanah tidak berkorelasi dengan populasi cacing tanah, biomassa cacing tanah, bobot umbi basah dan bobot umbi kering.

Kandungan C-organik berkorelasi positif menunjukkan bahwa semakin tinggi kandungan Corganik tanah yang terkandung maka semakin tinggi biomassa cacing tanah dan bobot umbi bawang merah. Berbeda dengan kadar air, bila kadar air semakin tinggi maka populasi cacing tanah, biomassa cacing tanah dan bobot umbi kering bawang merah akan semakin rendah. Kadar air dalam masing-masing bahan organik berpengaruh terhadap keadaan tanah yang mempengaruhi keberadaan cacing tanah. Kadar air baglog jamur paling baik bagi peningkatan cacing tanah, kadar air yang dimiliki baglog jamur sekitar 54,9\%, bahan jenis baglog jamur ini diberikan ke tanah sebelum tanam sehingga memperbaiki kelembaban dan

Tabel 6. Sifat kimia tanah pada pengamatan 70 HST

\begin{tabular}{cccccc}
\hline No. & Perlakuan & $\mathrm{pH}$ & C-organik $(\%)$ & Kadar air $(\%)$ & Suhu $\left({ }^{\circ} \mathrm{C}\right)$ \\
\hline 1 & $\mathrm{~B}_{0} \mathrm{P}_{1}$ & 6,51 & 1,09 & 25,01 & 28,27 \\
2 & $\mathrm{~B}_{0} \mathrm{P}_{2}$ & 6,62 & 1,22 & 23,63 & 27,2 \\
3 & $\mathrm{~B}_{0} \mathrm{P}_{3}$ & 6,73 & 1,17 & 22,17 & 28,93 \\
4 & $\mathrm{~B}_{0} \mathrm{P}_{4}$ & 6,72 & 1,25 & 20,81 & 28 \\
5 & $\mathrm{~B}_{1} \mathrm{P}_{1}$ & 6,31 & 1,12 & 22,61 & 28,23 \\
6 & $\mathrm{~B}_{1} \mathrm{P}_{2}$ & 6,39 & 1,17 & 21,86 & 28,77 \\
7 & $\mathrm{~B}_{1} \mathrm{P}_{3}$ & 6,52 & 0,98 & 18,34 & 28,7 \\
8 & $\mathrm{~B}_{1} \mathrm{P}_{4}$ & 6,77 & 1,83 & 25,35 & 28,47 \\
\hline
\end{tabular}

Keterangan : $\mathrm{B}_{0}$ ( Tanpa pupuk Hayati) $; \mathrm{B}_{1}$ ( Diberi pupuk hayati) $; \mathrm{P}_{1}$ ( Pupuk kandang ayam) $; \mathrm{P}_{2}$ ( Pupuk kandang sapi) $; \mathrm{P}_{3}$ ( Baglog jamur) $; \mathrm{P}_{4}$ (Kompos Jerami). 
Tabel 7 . Uji korelasi sifat kimia tanah dengan populasi dan biomassa cacing dan produksi tanaman bawang merah (Allium ascalonicum L.) pada pengamatan 70 HST.

\begin{tabular}{|c|c|c|c|c|}
\hline \multirow[b]{2}{*}{$\begin{array}{l}\text { Koefisien Korelasi } \\
\text { (r) }\end{array}$} & \multicolumn{4}{|c|}{ Koefisien Korelasi (r) } \\
\hline & $\begin{array}{c}\text { Populasi Cacing tanah } \\
\left({\left.\text { ekor } \mathrm{m}^{-2}\right)}^{\text {a }}\right.\end{array}$ & $\begin{array}{c}\text { Biomassa Cacing tanah } \\
\left(\text { gram m}^{-2}\right)\end{array}$ & $\begin{array}{c}\text { Bobot Umbi basah } \\
\text { (gram) }\end{array}$ & $\begin{array}{c}\text { Bobot Umbi kering } \\
\text { (gram) }\end{array}$ \\
\hline $\mathrm{pH}$ & $0,07^{\mathrm{tn}}$ & $0,03^{\text {tn }}$ & $0,07^{\text {tn }}$ & $0,10^{\text {tn }}$ \\
\hline C- organik $(\%)$ & $0,08^{\mathrm{tn}}$ & $0,49^{* *}$ & $0,68^{* *}$ & $0,63^{* *}$ \\
\hline Kadar air $(\%)$ & $-0,47^{* *}$ & $-0,46^{* *}$ & $-0,41^{* *}$ & $0,29^{\text {tn }}$ \\
\hline Suhu $\left({ }^{\circ} \mathrm{C}\right)$ & $0,27^{\mathrm{tn}}$ & $0,38^{\mathrm{tn}}$ & $0,11^{\text {tn }}$ & $0,009^{\text {tn }}$ \\
\hline
\end{tabular}

Keterangan : tanda $(* *)$ menunjukkan adanya korelasi yang sangat nyata, tanda (tn) menunjukkan bahwa tidak berkorelasi

temperatur dari tanah tersebut. Bahan-bahan yang terkandung dalam baglog jamur yang membuat poripori tanah lebih luas dibandingkan pupuk kandang ayam yang termasuk pupuk yang masih mengandung sekam padi sehingga sulit didekomposisi. Bahan organik yang memliki kadar air yang cocok seperti baglog jamur maka populasi cacing tanah akan meningkat diiringi dengan peningkatan biomassa cacing tanah dan produksi bawang merah.

Populasi dan biomassa cacing tanah pada kedalaman 0-10 cm berkorelasi positif sangat nyata dengan bobot umbi basah bawang merah dan bobot umbi kering bawang merah Hal tersebut menunjukkan bahwa pada kedalaman 0-10 cm pengamatan $70 \mathrm{HST}$, semakin tinggi populasi cacing tanah dan biomassa cacing tanah akan semakin meningkatkan bobot umbi basah dan bobot umbi kering bawang merah. Terjadinya korelasi positif hanya pada kedalaman 0$10 \mathrm{~cm}$ karena pembentukkan umbi bawang merah berada pada kedalaman $0-10 \mathrm{~cm}$. Pada budidaya bawang merah jika umbi ditanam lebih dalam maka pembentukkan umbi akan semakin kecil (Wibowo, 2011).

\section{KESIMPULAN}

Hasil penelitianmenunjukkan bahwa pemberian pupuk hayati (Bio max grow) meningkatkan populasi cacing tanah pada pengamatan 37 HST di kedalaman 10-20 cm dan meningkatkan populasi cacing tanah pada pengamatan $70 \mathrm{HST}$ di kedalaman 0-10 cm dan 10-20 cm serta biomassa cacing tanah dan produksi bawang merah. Pemberian baglog jamur memberikan pengaruh yang terbaik diantara bahan organik lainnya terhadap populasi cacing tanah, biomassa cacing tanah dan produksi bawang merah. Pupuk kandang sapi berpengaruh lebih tinggi dibandingan pupuk kandang ayam dan kompos jerami, sedangkan pupuk kandang ayam dan kompos jerami tidak berbeda. Sedangkan interaksi hanya terjadi pada populasi cacing tanah pada pengamatan $37 \mathrm{HST}$ di kedalaman 0-10 cm, dan pada variabel lainnya tidak terdapat interaksi. Terdapat korelasi positif antara C-organik dengan biomassa cacing tanah dan bobot bawang merah, korelasi positif lainnya antara populasi cacing tanah terhadap bobot bawang merah. Sedangkan kadar air memberikan korelasi negatif terhadap populasi biomassa cacing tanah dan bobot bawang merah. 


\section{DAFTAR PUSTAKA}

Dermiyati. 2015. Sistem Pertanian Organik Berkelanjutan. Plantaxia. Lampung.

Direktorat Pangan dan Pertanian, 2014. Studi Perkuliahan Rencana Pembangunan Jangka Menengah Nasional(RPJMS) Bidang Pangan dan Pertanian 2015. Direktorat Pangan dan Pertanian, Bappenas Jakarta.

Dwi, S, dan Santoro. 2011. Eksistensi Cacing Tanah pada Lingkungan Berbagai Sistem Budidaya Tanaman. Prossiding Seminar Nasional VIII Pendidikan Biologi. Universitas Sebelas Maret. Surakarta. Hlm : 97-101.

Herliyanto, Jimmy. 2010. Pengaruh Sistem Olah Tanah terhadap Cacing Tanah pada Pertanaman Lahan Tebu di Great Giant Peneapple. Skripsi. Universitas Lampung. Lampung

Kemas, Ali, H. 2005. Dasar-Dasar Ilmu Tanah. PT Raja Grafindo Persada. Jakarta.

Kementrian Pertanian, 2015. Produksi Pangan Indonesia. Diakses pukul 15.34 pada tanggal 19 Agustus 2017.
Ketut, M.A., Tika W., dan Wijaya. 2017. Pengaruh perbandingan komposisi bahan baku terhadap kualitas kompos dan lama waktu pengomposan. Jurnal Biosistem dan Teknik Pertanian. 5(1).

Maftu'ah, E., Maulia, A. S. 2009. Komunitas Cacing Tanah pada Beberapa Penggunaan Lahan Gambut di Kalimantan Tengah. Berita Biologi 9(4).

Marzuki, Sufardi, dan Manfarizah. 2011. Sifat fisika dan hasil kedelai (Glycine max L.) pada tanah terkompaksi akibat cacing tanah dan bahan organik. Jurnal Manajemen Sumberdaya Lahan. 1 (1) : 23-31.

Prayoga, E. S. 2016. Respons Tanaman Bawang Merah (Allium ascalonicum L.) Akibat Aplikasi Pupuk Hayati dan Pupuk Majemuk NPK dengan Berbagai Dosis. Skripsi. Universitas Lampung. Lampung. Hlm. 5.

Rao, 1994. Mikroorganisme Tanah dan Pertumbuhan. UI Press. Jakarta. hlm. 352

Tambunan Willy. A., Sipayung R.,dan Sitepu F.R. 2014. Pertumbuhan dan Produksi Bawang Merah (Allium ascalonicum L.) dengan Pemberian Pupuk Hayati pada Berbagai Media Tanam. Jurnal Online Agroteknologi. 2(2) : 825-836. 